\title{
Trends in de kwaliteit van de arbeid in Nederland en Europa
}

\author{
Irene Houtman en Seth van den Bossche*
}

\begin{abstract}
In dit artikel wordt aan de hand van de Nationale Enquête Arbeidsomstandigheden (NEA) en de European Working Conditions Survey (EWCS) ingegaan op de vragen (I) welke ontwikkelingen zichtbaar zijn in de kwaliteit van de arbeid van Nederlandse werknemers, en (2) waar de kwaliteit van werk in Nederland staat ten opzichte van die in de rest van Europa. Globalisering, arbeidsmarktverschuiving naar de dienstensector en technologische vernieuwingen worden als de veronderstelde drijfveren achter deze ontwikkelingen gezien. Intensivering van werk, mogelijk als gevolg van de globalisering, is wel in Europa waar te nemen maar niet (meer) in Nederland. Van koploper op het gebied van werkdruk tot het jaar 2000 behoort Nederland inmiddels tot de middenmoot. Tevens is er een reeds langer bestaande trend naar meer flexbanen waar te nemen en recent een afname van baanzekerheid. Mogelijk als gevolg van de toename van de dienstensector, blijven in $\mathrm{Ne}$ derland de meer traditionele arbo-risico's als lichamelijke en omgevingsbelasting, lange werktijden alsook het werken in ploegendienst gelijk of namen zelfs licht af. Sociale steun van leiding en collega's is hoog en nam recent nog verder toe. Het werken met de computer en telewerken zijn dankzij technologische vernieuwingen en verschuiving van het werk naar de dienstensector goed aangeslagen onder werkend Nederland. Dit gebeurt in Nederland veel meer dan gemiddeld in Europa. Werken met de computer hangt samen met een goede kwaliteit van de arbeid, al neemt het percentage werknemers dat risico loopt op bewegingsapparaatklachten toe als gevolg van toenemend langdurig (meer dan vier tot zes uur per dag) beeldschermwerk. De kwaliteit van de arbeid in Nederland is vergeleken met het Europese gemiddelde behoorlijk hoog, met uitzondering van de blootstelling aan werkgerelateerde agressie en geweld. In 'dienstenland' Nederland komt relatief veel agressie en geweld voor. Lichamelijk geweld op het werk neemt binnen Europa toe, maar Nederlandse gegevens laten geen recente toename van dit type geweld zien.
\end{abstract}

Trefwoorden: trends, kwaliteit van arbeid, Nederland, Europa

\section{Inleiding}

Het werken in Europa en ook in Nederland verandert. De vraag naar het soort van diensten en producten verschuift en de organisatie van het werk en de middelen waarmee men werkt veranderen. Er kunnen drie verschillende globale oorzaken worden genoemd van deze veranderingen in het werk.

Ten eerste is er sprake van globalisering. Hiermee wordt de wereldwijde integratie van economieën bedoeld. Dit heeft vooral tot toegenomen concurrentie tussen bedrijven geleid, tot verschuiving van soorten bedrijven over de aardbol en tot 'outsourcing' van allerlei activiteiten uit de organisatie, onder andere naar lagelonenlanden. In zijn veelgeprezen boek heeft Flanagan (2006) onderzocht welke effecten globalisering op arbeidsvoorwaarden (arbeidsuren, beloning en veiligheid) en werknemerrechten (ge-

* De auteurs zijn werkzaam bij TNO Kwaliteit van Leven| Arbeid te Hoofddorp; correspondentieadres: irene.houtman@tno.nl. 
dwongen arbeid, kinderarbeid, non-discriminatie) heeft. Hij vond geen empirische onderbouwing van een verslechtering door globalisering.

Figuur I Werknemers in Nederland en de EU-I 2 met een tijdelijk contract als percentage van alle werknemers, 1990-2009

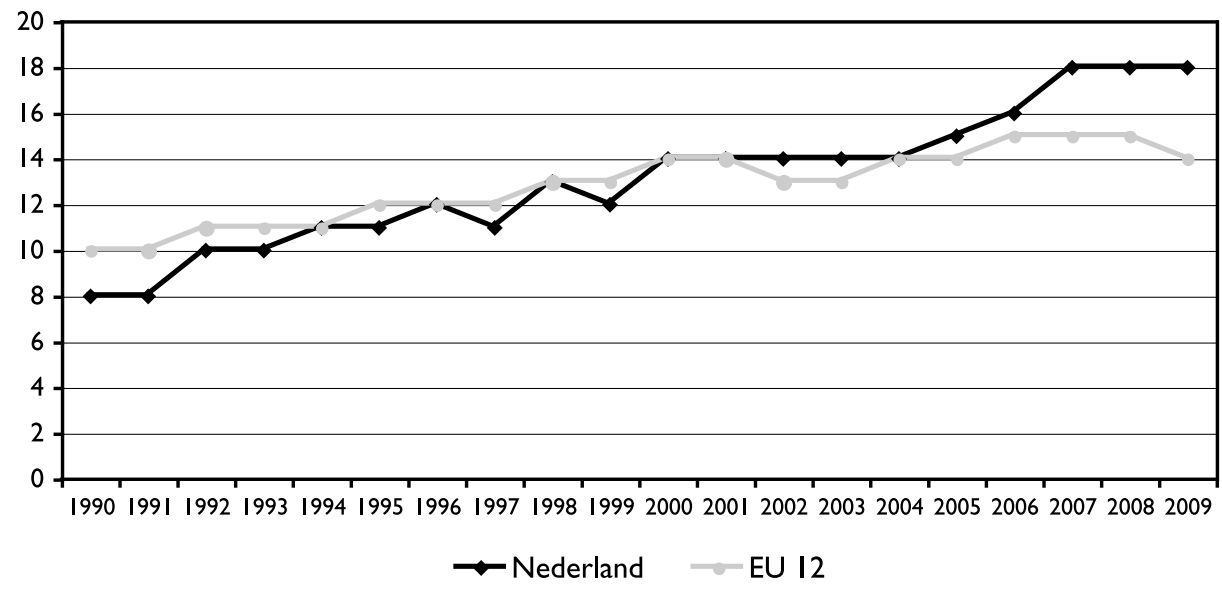

Bron: Eurostat/Labour Force Survey

Men kan evenwel aannemen dat globalisering heeft geleid tot flexibilisering van werk inclusief deeltijdwerk, uitzendwerk, en onafhankelijke contractering van werkenden (vermeld door Houtman et al., 2008; Kawachi, 2008; EU-OSHA, 2007). Figuur 1 laat inderdaad een sterke toename van tijdelijke contracten in Nederland en Europa zien sinds 1990. Nederland had in 1990 een geringer percentage tijdelijke contracten dan de EU. Anno 2009 was het echter hoger dan het Europese gemiddelde, namelijk 18\% versus $14 \%$ van alle werknemers. Werkgevers worden door tijdelijke contracten flexibeler en hun personele kosten zullen vaak lager zijn. Voor werknemers kan dit echter gepaard gaan met minder baanzekerheid en minder bescherming door bonden en arbeids(omstandigheden)wetgeving, zoals De Cuyper et al. (2008) en Kawachi (2008) veronderstellen.

Een tweede ontwikkeling is de 'tertiairisering' van de arbeidsmarkt, ofwel de toename van de vraag naar arbeid in de dienstensector ten koste van de werkgelegenheid in industrie en landbouw. Deze ontwikkeling is al in het begin van de twintigste eeuw ingezet, maar hangt de laatste decennia waarschijnlijk ook samen met de globalisering, want het outsourcen van handarbeid naar lagelonenlanden leidt ertoe dat er vooral een diensteneconomie overblijft. Deze verschuiving in de arbeidsmarkt is zowel op nationaal als op Europees niveau te zien (Peña-Casas \& Pochet, 2009; European Agency, 2007). Figuur 2 toont de verschuivingen in de Nederlandse en Europese arbeidsmarkt vanaf 1995.

Er is zowel sprake van een stijging in werkgelegenheid in de profit als in de non-profit dienstensectoren, dat wil zeggen in de zakelijke dienstverlening (banken en hieraan gelieerde bedrijven, adviesbureaus e.d.), alsook in sectoren als de zorg, het onderwijs en de overheid, waarbij contact met cliënten een rol speelt. Op dit laatste aspect wordt in dit artikel nog teruggekomen. 
Figuur 2 Veranderingen in de arbeidsmarkt in Nederland en de EU-I5, 1995-2007

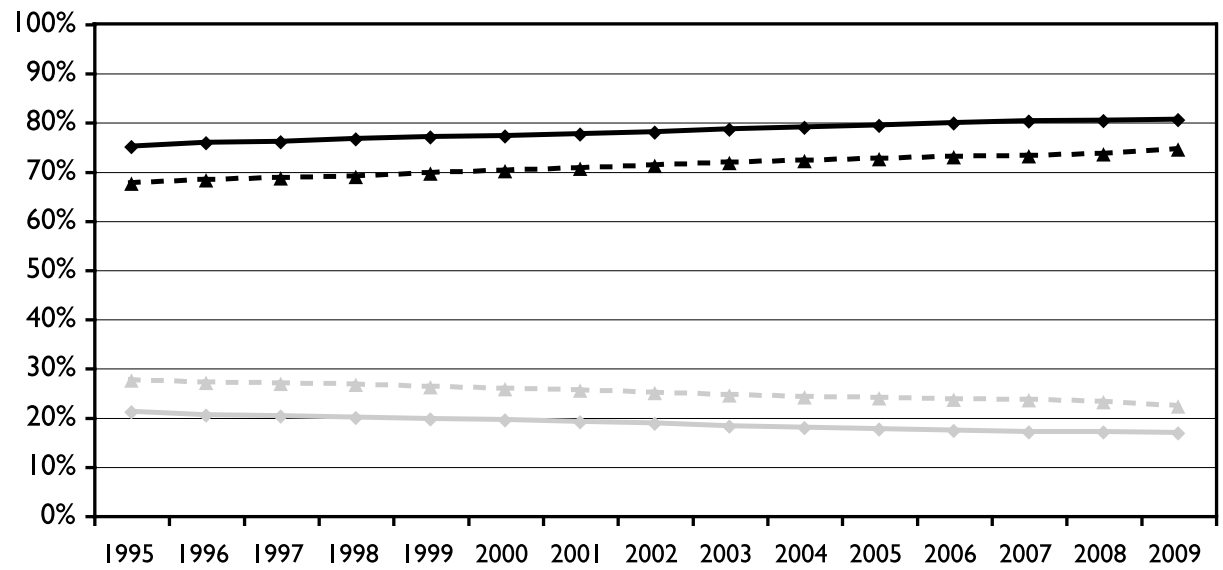

- -A- - Diensten EU I5 $=-=^{-=}=$Industrie EU I5 $\longrightarrow$ Diensten NL $\longrightarrow$ Industrie NL

Bron: Eurostat/Labour Force Survey

Ten derde hebben zich sinds de opkomst van de computer en het internet vernieuwingen voorgedaan. Niet alleen is veel handmatig werk verdwenen en zijn kwalificatie-eisen voor werknemers veranderd, maar ook is 'het nieuwe werken' geïntroduceerd. Hiermee wordt telewerken, thuiswerken of mobiel werken bedoeld. Vele werkzaamheden kunnen nu onafhankelijk van tijd en plaats worden uitgevoerd, dus onderweg in de trein, thuis, en volgens enkele televisiespots zelfs op een exotisch strand of midden in het oerwoud. De grenzen tussen werken en vrije tijd zijn hiermee rekbaarder geworden. Werk kan plaatsvinden op 'niet-werk'-momenten, en dat is een nieuw aspect, kan ten koste gaan van rust en herstel, alsook van verplichtingen in de privésfeer.

'Hard bewijs' voor de invloed van globalisering, tertiairisering en computerisering op de kwaliteit van het werk ontbreekt nogal eens. Nader onderzoek zou wenselijk zijn. Niettemin formuleren we - op basis van onderzoeksliteratuur, kwantitatieve gegevens en meningen van internationale experts - onderstaande verwachtingen.

Als gevolg van de globalisering zal er sprake zijn geweest van een intensivering van werk, meer reorganisaties en een toenemend gevoel van werkonzekerheid. Ook zullen er meer tijdelijke contracten zijn gesloten en zal het aandeel werkenden dat werk vindt via uitzendbureaus of als oproepkracht toegenomen zijn.

De verschuiving van de werkgelegenheid naar de dienstensector heeft naar verwachting geleid tot een afname van fysiek zwaar werk, een toename van computerwerk en een toename van risico's die typisch zijn voor zogenaamde 'contactuele beroepen', zoals agressie en geweld door derden (klanten, patiënten, leerlingen, passagiers). Dit laatste verschijnsel is uiteraard niet alleen een effect van tertiairisering, maar ook van wat genoemd wordt de verruwing van de normen en waarden en omgangsvormen, die ook buiten de wereld van het werk vastgesteld zijn.

Het 'nieuwe werken' hangt samen met de toename van het werken met de computer en impliceert telewerken, thuiswerken en mobiel werken. Daarnaast zal men vaker op flexibele plaatsen en met flexibele werktijden aan het werk zijn gegaan. Ook zullen 
problemen met de werk-thuisbalans toegenomen zijn. De autonomie zal - met name bij het werken met de computer - toegenomen zijn, maar waarschijnlijk ook de eisen die het werk stelt, zoals de complexiteit van werk, de leer- en ontplooiingsmogelijkheden en ook zal er waarschijnlijk meer worden overgewerkt.

Naast genoemde drie veranderingen in het werk zelf (globalisering, tertiairisering en computerisering), verandert ook de aanbodzijde, de 'menskant', van arbeid. De arbeidsmarkt vergrijst, feminiseert, wordt diverser en het gemiddelde opleidingsniveau stijgt (Bijl et al., 2009; Sanders et al., 2010). Dit leidt tot andere capaciteiten, vaardigheden en belastbaarheid van (potentiële) werknemers.

Met behulp van Europese data zal tevens een vergelijking worden gemaakt tussen de Nederlandse werknemers en die in de rest van Europa. De vraagstellingen die centraal staan in dit artikel zijn:

- welke ontwikkelingen zijn zichtbaar in de ervaren kwaliteit van arbeid door Nederlandse en Europese werknemers; en

- waar staat Nederland ten opzichte van Europa op het gebied van arbeidsomstandigheden?

Het doel van dit artikel is om aan de hand van nationaal en internationaal monitoronderzoek te bekijken hoe de kwaliteit van arbeid zich in Nederland heeft ontwikkeld, in samenhang met voornoemde veranderingen. De ontwikkelingen in arbeidsomstandigheden zullen worden besproken aan de hand van de volgende indeling:

1 Psychosociale factoren in het werk, zoals werkdruk of intensivering van werk, autonomie, ontplooiingsmogelijkheden en sociale relaties op het werk;

2 Ergonomische factoren (zoals duwen, tillen, trekken, houdingsbelasting) en omgevingsfactoren (zoals lawaai, vuil en gevaarlijk werk);

3 Het werken met verschillende arbeidscontracten en baanzekerheid;

4 Werktijden, waaronder het aantal uren werk, overwerk, ploegendienst, alsook thuiswerken en telewerk en de werk-thuisbalans worden verstaan.

Niet overbodig is even stil te staan bij de vraag naar waarom we überhaupt belang stellen in trends in de kwaliteit van werk. Een belangrijke reden is dat een slechte kwaliteit van de arbeid leidt tot meer gezondheidsproblemen, meer verzuim en arbeidsongeschiktheid. Een recent aandachtspunt is dat aspecten van kwaliteit van de arbeid samenhangen met het al dan niet langer doorwerken (Ybema et al., 2009). In dit artikel wordt niet gekeken naar trends in de gezondheid van werkend Nederland. Uit de NEA (Klein Hesselink et al., 2009), alsook uit cijfers van de leefsituatieonderzoeken tot 2002 (Houtman et al., 2004) blijkt dat de psychische en fysieke gezondheid van Nederlandse werknemers behoorlijk stabiel is. We hebben hiermee echter geen informatie over de gezondheid van de werkenden die ziek uitvallen. Het verzuimcijfer van de Nederlandse beroepsbevolking daalt gestaag (zie ook Klein Hesselink et al., 2009; Koppes et al., 2010), maar dit lijkt meer het gevolg van striktere regels en mogelijk economische invloeden dan van een meer of minder gezonde beroepsbevolking. Onderzoek waarin werknemers worden gevolgd laat echter zien dat aspecten van kwaliteit van de arbeid, zoals tijdsdruk, taakeisen en gebrekkige regelmogelijkheden, bijdragen aan psychische klachten en verzuim (Häusser et al., 2010; Stansfeld \& Candy, 2006), klachten van het bewegingsapparaat (Bongers et al., 2002), en hart- en vaatziekten en sterfte daaraan (Kivimäki et al., 2006). Naast gezondheid is ook participatie van allen in de beroepsbevolking van toenemend belang. 


\section{Methoden}

Voor dit artikel zijn verschillende databronnen gebruikt. Nationale trends in arbeid worden beschreven aan de hand van de Nationale Enquête Arbeidsomstandigheden (NEA, Koppes et al., 2010). De NEA wordt uitgevoerd door TNO in samenwerking met het $C B S$. In het recente verleden werd de kwaliteit van de arbeid gemonitord door het CBS, als onderdeel van diverse leefsituatieonderzoeken (LSO, DLO en POLS ${ }^{1}$ ). Na de start van de NEA in 2003, die zich volledig toespitste op kwaliteit van arbeid, zijn de meeste indicatoren op het gebied van kwaliteit van arbeid geleidelijk verwijderd uit het POLS (gedeeltelijk in 2002 en volledig in 2003). De NEA startte aanvankelijk als tweejaarlijks onderzoek, maar is sinds 2005 jaarlijks uitgevoerd onder een representatieve steekproef van Nederlandse werknemers, dus exclusief zelfstandigen. Sinds 2008 vormt de Polisadministratie het steekproefkader van de NEA. De NEA 2003 had een netto respons van circa 10.000 werknemers. Na een verhoging van de steekproefomvang, bedraagt de gemiddelde netto respons sinds 2005 circa 23.000 werknemers per jaar. Werknemers uit de steekproef wordt een vragenlijst gestuurd; er wordt de mogelijkheid geboden om de vragenlijst via internet in te vullen of per post te retourneren.

Vanwege de (nog) beperkte looptijd van de NEA zal in de resultatensectie ook melding worden gemaakt van de ontwikkeling in aspecten van de kwaliteit van arbeid van vóór 2003 zoals die werden gemeten met het DLO of de POLS wanneer het om aspecten gaat die vergelijkbaar zijn met die nu op basis van de NEA worden besproken. Deze ontwikkelingen werden destijds systematisch besproken in het tweejaarlijkse 'Trends in arbeid' die voor het laatst is uitgegeven in 2004 (Houtman et al., 2004).

De vergelijking van trends in Nederland met Europese gegevens vindt plaats met de European Working Conditions Survey (EWCS) ${ }^{2}$. Deze survey heeft sinds 1990 iedere vijf jaar plaatsgevonden in alle Europese lidstaten. Per lidstaat zijn gemiddeld circa 1.000 werkenden (werknemers en zelfstandigen) geïnterviewd, met uitzondering van het jaar 2000, waarin gemiddeld circa 1.500 interviews per lidstaat plaatsvonden. Deze interviews vonden 'face to face' plaats na random steekproeftrekking per land. In dit artikel wordt als vergelijking de EU-15 ${ }^{3}$ gebruikt, omdat voor deze groep van Europese landen minimaal drie metingen (1995, 2000 en 2005) beschikbaar zijn. Waar relevant zullen voor 1990 de EU-12-gegevens worden vermeld. De EU-12 en de EU-15 onderscheiden zich in de jaren dat ze allebei kunnen worden geïdentificeerd echter nauwelijks van elkaar, zoals mag worden verwacht - ze overlappen tenslotte grotendeels.

Vanwege de grote aantallen respondenten zijn nagenoeg alle verschillen significant. Er zullen daarom geen significanties worden vermeld in de tabellen.

\section{Resultaten}

\section{Trends in psychosociale factoren}

\section{Werkdruk en regelmogelijkheden}

Het laatste decennium van de vorige eeuw stond in het teken van de stijgende werkdruk. In diverse, met name Europese rapporten is sprake van een sterke intensivering van arbeid als één van de 'emerging risks' van deze tijd. Nederlandse trendanalyses, bijvoorbeeld van Houtman et al. (2004) en Smulders (2008) laten op basis van het LSO, DLO 
en POLS zien dat het werken in een hoog tempo vanaf 1977 tot 1997, dus gedurende een periode van zo'n twintig jaar, bijna voortdurend stijgt met 1\%-punt per jaar. Aan het eind van de vorige eeuw ontstaat echter een afvlakking.

Tabel I Trends in werkdruk, autonomie en leermogelijkheden in Nederland en Europa, 1990-2005

$1990 \quad 1995 \quad 2000 \quad 2005$

\section{Werkdruk}

Snel moeten werken (\% erg hoog)

NL

EU-15

Werken met strakke deadlines (\% zeer vaak)

NL

EU-15

$\begin{array}{cccc}58 & 70 & 75 & 61 \\ 47^{*} & 54 & 56 & 61 \\ & & & \\ 36 & 43 & 65 & 61 \\ 50^{*} & 56 & 59 & 62\end{array}$

\section{Autonomie}

In staat zijn de taakvolgorde te kiezen of te veranderen (\% ja)

$\mathrm{NL}$

EU-I5

$\begin{array}{cccc}74 & 81 & 79 & 79 \\ 62 * & 66 & 65 & 64\end{array}$

In staat zijn de werkmethode te kiezen of te veranderen (\% ja)

NL

$\begin{array}{llll}-- & 81 & 82 & 73\end{array}$

EU-I5

In staat zijn de snelheid van werken te kiezen of aan te passen $(\%$ zeer vaak)

$\mathrm{NL}$

EU-15

76

$64^{*}$

Gebrek aan autonomie (schaal 3 items; \% helemaal geen autonomie $=$ 'nee' op alle drie bovenstaande vragen)

NL

EU-I5

\section{Werkinhoud en leren}

Leren van nieuwe dingen (\% erg hoog)

NL

EU-I5

Complex werk (\% erg vaak)

NL

EU-15

Monotoon werk (\% erg vaak)

$\mathrm{NL}$

EU-I5

Bron: EWCS; $*=\mathrm{EU}-12$

$\begin{array}{lll}-- & 73 & 71\end{array}$

Voor de periode 1990-2005 blijkt dat de ontwikkelingen in werkdruk en autonomie onder Nederlandse werknemers een wat ander patroon volgen dan in de rest van EU15 het geval is (zie tabel 1). In Europa (EU-15) is een voortdurende stijging van de werkdruk te zien van 1990 tot 2005, zowel in termen van de snelheid van werken als van het hebben van deadlines. In Nederland is alleen een stijging van werkdruk te zien tot het jaar 2000, daarna is de werkdruk gestabiliseerd en zelfs licht afgenomen. Was Nederland aan het eind van de vorige eeuw in de EU koploper op gebied van werkdruk, inmiddels zijn we een middenmoter. 
Tabel 2 Trends in werkdruk, autonomie, leermogelijkheden, sociale steun en agressie en geweld (alle werknemers, behalve waar anders vermeld), 2005-2009

\begin{tabular}{|c|c|c|c|c|c|}
\hline & 2005 & 2006 & 2007 & 2008 & 2009 \\
\hline \multicolumn{6}{|l|}{ Werkdruk } \\
\hline Tijdsdruk ( 2 items; \% ja op één of beide items) & -- & -- & 71 & 73 & 73 \\
\hline Taakeisen ( 4 items; \% ja > 2.5 op een schaal I-4) & -- & -- & 29 & 29 & 28 \\
\hline \multicolumn{6}{|l|}{ Autonomie } \\
\hline $\begin{array}{l}\text { Gebrek aan autonomie ( } 5 \text { items; \% helemaal geen autonomie, } \\
\text { ofwel 'nee' op alle vijf items) }\end{array}$ & -- & -- & 31 & 29 & 28 \\
\hline \multicolumn{6}{|l|}{ Leren } \\
\hline Is je werk gevarieerd? (\% ja) & -- & -- & 71 & 72 & 65 \\
\hline Vereist het werk dat je nieuwe dingen leert? (\% ja) & -- & -- & 46 & 51 & 45 \\
\hline Vereist uw werk creativiteit? (\% ja) & -- & -- & 60 & 61 & 56 \\
\hline Cognitieve taakeisen ( 3 items; $\%$ ja $>2.5$ op schaal I-4) & -- & -- & 82 & 79 & 77 \\
\hline \multicolumn{6}{|l|}{ Steun } \\
\hline Sociale steun leiding ( 4 items; $\%$ ja $>2.5$ op schaal I-4) & -- & -- & 69 & 71 & 72 \\
\hline Sociale steun collega's ( 4 items; \% ja > 2.5 op schaal I-4) & -- & -- & 93 & 93 & 93 \\
\hline \multicolumn{6}{|l|}{ Agressie en geweld } \\
\hline \multicolumn{6}{|l|}{$\begin{array}{l}\text { Afg. } 12 \text { mnd. lichamelijk geweld door klanten, patiënten, } \\
\text { leerlingen of passagiers e.d. (\% ja) }\end{array}$} \\
\hline Vrouwen & 9 & 8 & 8 & 9 & 9 \\
\hline Mannen & 6 & 5 & 4 & 4 & 4 \\
\hline Totaal & 7 & 6 & 6 & 6 & 6 \\
\hline \multicolumn{6}{|l|}{ Idem, lichamelijk geweld door leiding of collega's (\% ja) } \\
\hline Vrouwen & 0,3 & 0,5 & 0,2 & 0,3 & 0,3 \\
\hline Mannen & 1 & I & 1 & 1 & I \\
\hline Totaal & I & I & 1 & 1 & I \\
\hline
\end{tabular}

Bron: TNO/CBS-NEA

In het Europese arbeidsomstandighedenonderzoek is ook gevraagd naar de autonomie in het werk, de mogelijkheid de werkvolgorde, de werkmethode of de snelheid te kiezen of te veranderen. Op al deze aspecten scoort de Nederlandse werknemer relatief gunstig, dus beter dan het EU-gemiddelde. Gemiddeld zo'n $80 \%$ van de werknemers geeft aan dat ze deze keuze of beïnvloedingsmogelijkheid heeft, tegen gemiddeld $70 \%$ in de rest van Europa. Tabel 1 laat tevens zien dat slechts 7 tot 10 procent van de werkenden in Nederland geen keuze of beïnvloedingsmogelijkheid heeft ten aanzien van werkvolgorde, werkmethode of werksnelheid. In de EU is dit gemiddeld 15-19\%.

In tabel 2 is te zien dat de tijdsdruk en taakeisen over de recente periode van 20072009 nagenoeg stabiel zijn. Intensivering van werk wordt vaak in combinatie bekeken met (gebrek aan) autonomie. Volgens het bekende 'Demands-Control'-model van Karasek (Karasek \& Theorell, 1990) is vooral een hoge werkdruk (tijdsdruk of taakeisen) in combinatie met een gebrek aan regelmogelijkheden of autonomie een risico voor de gezondheid en welzijn. Tabel 2 laat zien dat het gebrek aan autonomie in Nederland van 2007 op 2009 licht is afgenomen, van 31\% naar 28\%.

Los van een hoge werkdruk heeft een gebrek aan autonomie op zichzelf ook negatieve gevolgen voor de werknemer en de organisatie. Zo hangt een gebrek aan autonomie samen met een hoog verzuim en een verhoogd risico op gezondheidsproblemen (Häusser et al., 2010).

De gesignaleerde ontwikkelingen in de werkdruk zijn voor mannen en vrouwen nagenoeg gelijk. Maar mannen rapporteren vaker een gebrekkige autonomie dan vrouwen. 
Mogelijk speelt de aard van het beroep hierin een rol. Mannen werken bijvoorbeeld relatief vaker in bouw en de industrie, waar de regelmogelijkheden wat beperkter zijn.

\section{Leer- en ontplooiingsmogelijkheden}

Een aspect van werk dat Karasek \& Theorell (1990) naast autonomie ook associëren met regelmogelijkheden is de mogelijkheid om kennis en vaardigheden te ontwikkelen in het werk. Dit aspect van werk is bovendien iets wat goed aansluit bij de huidige discussie over leren op de werkplek en de voorwaarden waar werk aan moet voldoen wil het bijdragen aan duurzame inzetbaarheid van werknemers.

Tabel 2 laat zien dat er op basis van onze nationale cijfers geen eenduidige trend zichtbaar is over de periode 2007 tot en met 2009. Het lijkt erop dat na 2008, het jaar dat de crisis zich openbaarde, de ontwikkelmogelijkheden in de vorm van gevarieerd werk, nieuwe dingen leren in het werk en of het werk creativiteit in het werk vereist zich in negatieve zin keerden. Volgende metingen moeten laten zien of deze trend zich doorzet.

In het LSO/DLO/POLS van vóór 2003 zaten ook al een paar vragen over ontplooiingsmogelijkheden alsook over het tegendeel hiervan, het hebben van eentonig werk. Ontplooiingsmogelijkheden waren in de periode 1994-2002 redelijk stabiel (Houtman et al., 2004). Van de werkenden in Nederland rapporteerde 22 tot $26 \%$ een lage mate van ontplooiingsmogelijkheden, een stabiele $7 \%$ van de werkenden rapporteerde eentonig werk (Houtman et al., 2004). Er is wel een aanzienlijk gat (van 2002 tot 2007) op dit aspect van kwaliteit van arbeid, maar in de jaren dat het gemeten is, bleek dit een redelijk stabiel gegeven dat recent mogelijk onder de recessie te lijden heeft.

In Europa zijn ook gegevens over leer- of ontplooiingsmogelijkheden beschikbaar op basis van de EWCS (zie tabel 1). Hier zien we dat leermogelijkheden in het werk en de complexiteit van werk van 1995 tot 2005 in Nederland toenemen en de eentonigheid (monotoon werk) afneemt. Hier zijn nog geen gegevens uit 2010 beschikbaar die mogelijke effecten van de recessie kunnen laten zien.

\section{Sociale steun op het werk en agressie en geweld}

Een heel ander aspect van psychosociale arbeidsbelasting is de relatie met een ander in het werk. Het kan hierbij gaan om werken met collega's, leidinggevenden of met 'derden' zoals klanten, leerlingen, patiënten of passagiers. Het werken met 'derden' is typisch een indicator voor het werken in de dienstensector. Ook in tabel 2 staan de trends in sociale steun en in agressie en geweld zoals ze met de NEA zijn gemeten. Het blijkt dat de sociale steun van leidinggevenden en collega's in Nederland relatief hoog is en licht toeneemt in de periode van 2007 tot en met 2009.

Lichamelijk geweld van klanten, patiënten, passagiers of leerlingen is redelijk stabiel in de periode 2005-2009 (zie tabel 2). Het komt vaker voor bij vrouwen dan bij mannen. Werkenden in de zorg vormen een uitschieter op dit punt. Hier rapporteert maar liefst $22 \%$ van de werknemers dat ze te maken hebben gehad met lichamelijk geweld (Koppes et al., 2010).

Lichamelijk geweld door leidinggevenden of collega's komt bijna niet voor. Slechts één op de honderd werknemers zegt hiermee te maken te hebben gehad. Lichamelijk geweld door leidinggevenden en collega's wordt iets vaker gemeld door mannen dan door vrouwen. 
Sociale steun is geen onderwerp in het Europese arbeidsomstandighedenonderzoek, maar agressie en geweld is dat wel. Het wordt onder andere in toekomstscenario's (EUOSHA, 2007; Houtman et al., 2008) als een 'emerging risk' gezien. In de Europese gegevens is te zien dat lichamelijk geweld op het werk door klanten, patiënten, passagiers of leerlingen in Nederland opvallend vaak voorkomt. Dit zal onder andere te maken hebben met het feit dat Nederland een land is met een relatief grote dienstensector - en dus intensieve klantcontacten - waar de kans op agressie en geweld door 'derden' relatief groot is. De hier niet weergegeven Europese gegevens laten tevens zien dat lichamelijk geweld in het werk tot 2005 stijgt van 3\% in 1995 tot 5\% in 2005. In Nederland is een opzienbarend sterke stijging te zien in de periode 1995-2000: van 3 naar $9 \%$. In 2005 zakt het gemiddelde percentage werkenden dat lichamelijk geweld rapporteert weer terug naar $7 \%$.

\section{Trends in lichamelijke en omgevingsfactoren}

Vragenlijstonderzoek zoals bij de EWCS en NEA leent zich uiteraard vooral voor lichamelijke en omgevingsrisico's die werkenden zelf kunnen waarnemen, dus niet voor een aantal gevaarlijke stoffen (bijvoorbeeld biologische of chemische stoffen, nanodeeltjes) en straling. Over dit type risico's wordt hier dan ook niet gerapporteerd.

In Europees perspectief heeft werkend Nederland betrekkelijk weinig te maken met ongunstige houdingen, tillen van zware lasten en lawaai in het werk (zie tabel 3). Dit wordt deels verklaard door het feit dat Nederland een diensteneconomie heeft en relatief minder werkgelegenheid heeft in de industrie en de landbouw (zie ook figuur 2). Ook wanneer we binnen sectoren zoals de industrie en de bouw kijken naar de meer traditionele arbo-risico's in Nederland, dan blijkt dat de werkenden in die sectoren nog steeds gunstig afsteken tegen de rest van Europa (Bakhuys Roozeboom e.a., 2008).

Er is echter ook een aantal risico's waarbij het aandeel Nederlandse werknemers dat hier (erg vaak) mee te maken heeft ongeveer gelijk is aan het Europese gemiddelde. Het gaat hierbij met name om repeterende bewegingen, mogelijk door het intensieve computergebruik in Nederland. 
Tabel 3 Trends in lichamelijke en omgevingsrisico's in Nederland en in Europa, 19902005

\begin{tabular}{lcccc}
\hline & 1990 & 1995 & 2000 & 2005 \\
\hline Werken in ongunstige houding (\% erg vaak) & & & & \\
NL & 24 & 28 & 30 & 25 \\
EU-15 & $42^{*}$ & 44 & 45 & 44 \\
Tillen van zware lasten (\% erg vaak) & & & & \\
NL & 21 & 25 & 27 & 22 \\
EU-15 & $30 *$ & 32 & 36 & 34 \\
Repeterende bewegingen (\% erg vaak) & & & & \\
NL & -- & 57 & 66 & 61 \\
EU-15 & & 56 & 57 & 62 \\
Werken met beschermende kleding (\% erg vaak) & -- & 24 & 19 & 26 \\
NL & -- & 24 & 28 & 32 \\
EU-15 & & & & 20 \\
Lawaai in het werk (\% erg vaak) & 19 & 24 & 22 & 29 \\
NL & $32 *)$ & 26 & 28 & 29 \\
EU-15 & & & &
\end{tabular}

Bron: EWCS; $*=\mathrm{EU}-12$

De Nederlandse werknemer ervaart sinds 2005 minder lichamelijke belasting in het werk, zoals minder kracht hoeven te zetten, minder houdingsproblemen en minder repeterend werk (tabel 4). De hier gesignaleerde trends liggen in de lijn van de verwachting en sluiten aan bij de algemene trend dat werkenden steeds meer met kennis en informatie werken en minder werk doen waar sprake is van de meer traditionele lichamelijke en omgevingsrisico's.

Ten aanzien van deze lichamelijke risico's zijn er niet zozeer trendverschillen tussen mannen en vrouwen, maar is er in een aantal gevallen wel sprake van sekseverschillen. Zo ervaren vrouwen minder vaak gevaarlijk werk en minder trillingen of schudden als gevolg van het bedienen van apparaten, maar ervaren ze in vergelijkbare mate als mannen dat ze (veel) kracht moeten gebruiken, in ongunstige houdingen moeten werken en herhalende bewegingen moeten maken (tabel 4).

\section{Trends in arbeidscontracten en baanzekerheid}

Het aandeel tijdelijke contracten in Nederland is in de afgelopen twee decennia meer dan verdubbeld (zie figuur 1). In 1990 lag het aandeel tijdelijke werknemers in Nederland iets onder het EU-gemiddelde (8\% versus 10\%), in 2009 lag het er ruim boven (18\% versus $14 \%)$.

Ook in de NEA is de daling in het percentage vaste contracten terug te zien (Smulders \& Goudswaard, 2010). Deze ontwikkelingen gaan, wellicht logischerwijs, gepaard met een afnemend gevoel van baanzekerheid van werkend Nederland. Dit gevoel wordt versterkt door de recente recessie, zoals duidelijk zichtbaar is in tabel 4, onderaan. Daar waar in 2007 en 2008 gemiddeld één op de zes Nederlandse werknemers zich zorgen over het behoud van zijn of haar baan, was dat bijna één op de vier werknemers in 2009. 
Tabel 4 Trends in lichamelijke werkbelasting en baanonzekerheid, 2005-2009

\begin{tabular}{|c|c|c|c|c|c|}
\hline & 2005 & 2006 & 2007 & 2008 & 2009 \\
\hline \multicolumn{6}{|c|}{ Lichamelijke werkbelasting } \\
\hline \multicolumn{6}{|c|}{ In werk kracht moeten gebruiken (\% ja) } \\
\hline Vrouwen & 44 & 43 & 38 & 40 & 38 \\
\hline Mannen & 50 & 48 & 44 & 46 & 43 \\
\hline Totaal & 47 & 46 & 41 & 43 & 41 \\
\hline \multicolumn{6}{|c|}{ Werk doen in een ongunstige houding (\% ja) } \\
\hline Vrouwen & -- & -- & 37 & 36 & 34 \\
\hline Mannen & -- & -- & 39 & 38 & 38 \\
\hline Totaal & -- & -- & 38 & 37 & 36 \\
\hline \multicolumn{6}{|c|}{ Werk doen met herhalende bewegingen (\% ja) } \\
\hline Vrouwen & -- & -- & 57 & 55 & 54 \\
\hline Mannen & -- & -- & 58 & 58 & 57 \\
\hline Totaal & -- & -- & 58 & 57 & 56 \\
\hline \multicolumn{6}{|c|}{ Gevaarlijk werk doen (\% ja) } \\
\hline Vrouwen & 12 & 13 & -- & 17 & -- \\
\hline Mannen & 36 & 35 & -- & 33 & -- \\
\hline Totaal & 25 & 25 & -- & 26 & -- \\
\hline \multicolumn{6}{|c|}{$\begin{array}{l}\text { In werk gebruik maken van gereedschap, apparaat of } \\
\text { voertuig dat trillingen of schudden veroorzaakt (\% ja) }\end{array}$} \\
\hline Vrouwen & -- & -- & 7 & 7 & 7 \\
\hline Mannen & -- & -- & 29 & 28 & 28 \\
\hline Totaal & -- & -- & 19 & 19 & 18 \\
\hline \multicolumn{6}{|c|}{ Baanonzekerheid } \\
\hline \multicolumn{6}{|c|}{ Risico lopen om baan te verliezen (\% ja) } \\
\hline Vrouwen & -- & -- & 15 & 16 & 19 \\
\hline Mannen & -- & -- & 18 & 19 & 26 \\
\hline Totaal & -- & -- & 17 & 17 & 23 \\
\hline \multicolumn{6}{|c|}{ Zich zorgen maken over behoud baan (\% ja) } \\
\hline Vrouwen & -- & -- & 16 & 17 & 21 \\
\hline Mannen & -- & -- & 17 & 19 & 24 \\
\hline Totaal & -- & -- & 16 & 18 & 23 \\
\hline
\end{tabular}

Bron: TNO/CBS-NEA

\section{Trends in het 'nieuwe werken': werktijden, computer- en telewerk en de werk-thuisrelatie}

Wanneer de werktijden in Nederland vergeleken worden met die in Europa, blijkt dat de Nederlandse werknemer relatief weinig uren maakt (tabel 5). Gemiddeld genomen werkt men in Nederland 4,5 uur minder dan de gemiddelde Europese werknemer. Het grote (en stijgende) aandeel deeltijders in Nederland is hier in belangrijke mate debet aan. Volgens Gallie (2005) is dit ook de reden dat Nederland niet (meer) tot de werkdrukkoplopers in Europa behoort. 
Tabel 5 Trends in werktijden en werkplek in Nederland en in Europa, 1990-2005

\begin{tabular}{lcccc}
\hline & 1990 & $\mathbf{1 9 9 5}$ & $\mathbf{2 0 0 0}$ & $\mathbf{2 0 0 5}$ \\
\hline Aantal uren werk in de belangrijkste baan & & & & \\
NL & 36 & 35 & 33 & 33 \\
EU-15 & $41 *$ & 40 & 38 & 37 \\
Deeltijdwerkers (\%) & & & & \\
NL & 31 & 35 & 41 & 46 \\
EU-15 & $13 *$ & 16 & 18 & 20 \\
Telewerken met de computer vanuit huis (\%) & & & & \\
NL & -- & -- & 8 & 14 \\
EU-15 & -- & -- & 5 & 8 \\
Werk-thuisrelatie (\% niet erg/helemaal niet gunstig) & & & & \\
NL & -- & -- & 13 & 15 \\
EU-15 & -- & -- & 19 & 19 \\
\hline
\end{tabular}

Bron: EWCS; Labour Force Survey; * = EU-I2

In de meer recente periode 2005-2009 werkte de Nederlandse werknemer volgens contract gemiddeld 31 uur per week (tabel 6). Er is echter een aanzienlijk percentage werknemers (20-30\%) dat structureel overwerkt. Bij de mannen is dat maar liefst een derde. Ook het aantal uren dat gemiddeld wordt overgewerkt is bij mannen meer dan bij vrouwen.

Vergeleken met de rest van Europa komt computerwerk in Nederland veel voor. Volgens de EWCS is in Nederland het computergebruik in het werk gestegen van $42 \%$ in 1990 tot $72 \%$ in 2005 , terwijl dit in de EU-15 in 2005 nog slechts $49 \%$ was. De groei van de dienstensector is hier eveneens terug te zien.

In tabel 6 is te zien dat in de meer recente periode 2005-2009 in Nederland ongeveer $80 \%$ van de werknemers met een computer werkt. Een kwart van alle werknemers werkt zelfs zes uur of meer per dag achter de computer.

Het werken met computers wordt vaak geassocieerd met 'het nieuwe werken', dat wil zeggen het werken onafhankelijk van plaats en tijd, alsook met het bieden van leermogelijkheden in het werk. Klein Hesselink et al. (2009) laten zien dat het werken met computers inderdaad samenhangt met hoge werkdruk, maar ook met veel autonomie, ontplooiingsmogelijkheden en gevarieerd werk en juist met minder traditionele risico's als lichamelijke en omgevingsbelasting. De toenemende computerisering van werk hangt dus samen met een betere kwaliteit van de arbeid. Mogelijk speelt de groei van de dienstensector, naast de computerisering, hier ook een rol. Dit is nog nader onderzoek waard.

Het toegenomen computergebruik heeft echter ook een keerzijde, want het is met name het langdurig computergebruik, meer dan zes uur per dag, dat toeneemt (tabel 6). Onderzoek heeft namelijk laten zien dat het werken met beeldschermen gedurende zes uur of meer per dag voor mannen en vier uur of meer per dag voor vrouwen was geassocieerd met een verhoogd risico op klachten van het bewegingsapparaat (Blatter et al., 2000). 
Tabel 6 Trends in computer- en telewerk, werktijden en de werk-thuis balans, 20052009

$\begin{array}{lllll}2005 & 2006 & 2007 & 2008 & 2009\end{array}$

\section{Werktijden en overwerk}

Aantal uren werkzaam volgens contract

Vrouwen

Mannen

Totaal

Structureel overwerken (\% ja)

Vrouwen

Mannen

Totaal

Aantal overuren per week

Vrouwen

Mannen

Totaal

\section{Computer- en telewerk}

Uur/dag werken met computer (mannen en vrouwen samen),

geen computerwerk (\%)

I-6 uur computerwerk per dag (\%)

Meer dan 6 uur per dag computerwerk (\%)

$\begin{array}{lllll}25 & 26 & 26 & 26 & 26 \\ 36 & 36 & 37 & 36 & 36 \\ 31 & 31 & 32 & 32 & 31 \\ 22 & 22 & 19 & 22 & 21 \\ 33 & 34 & 32 & 33 & 30 \\ 28 & 29 & 28 & 28 & 26 \\ & & & & \\ 5 & 4 & 4 & 4 & 4 \\ 9 & 7 & 8 & 7 & 7 \\ 7 & 5 & 6 & 6 & 6\end{array}$

Telewerken (met behulp van computer, thuis of elders, werk doen dat ook op bedrijf/opdrachtgever uitgevoerd wordt (\% ja)

Vrouwen

Mannen

Totaal

\section{Afwijkende werktijden}

In ploegendienst werken (\% ja)

Vrouwen

Mannen

Totaal

's Avonds of 's nachts werken (\% ja)

Vrouwen

Mannen

Totaal

In het weekend werken $(\%$ ja)

Vrouwen

Mannen

Totaal

$\begin{array}{lllll}23 & 22 & 23 & 20 & 21 \\ 57 & 57 & 55 & 56 & 55 \\ 20 & 21 & 22 & 24 & 24\end{array}$

\section{Werk-thuisrelatie}

Missen of verwaarlozen van familie- of gezinsactiviteiten door werk $(\%$ ja)

Vrouwen

Mannen

Totaal

Missen of verwaarlozen van werkzaamheden door familie- of gezinsverantwoordelijkheden (\% ja)

\begin{tabular}{llllll} 
Vrouwen & 25 & - & 26 & 27 & 26 \\
Mannen & 30 & -- & 31 & 30 & 31 \\
Totaal & 27 & -- & 29 & 28 & 29 \\
\hline
\end{tabular}

Bron: TNO/CBS-NEA 
Tabel 6 presenteert ook de cijfers over afwijkende werktijden in Nederland. Dit meer 'traditionele' onregelmatig werken, bijvoorbeeld in ploegendienst of's avonds, 's nachts of in het weekend, blijkt in de periode 2005-2009 heel stabiel te zijn.

Dankzij de computer en allerlei nieuwe ontwikkelingen in de telecommunicatie is het in toenemende mate mogelijk, waar en wanneer men maar wil, te kunnen tele- of thuiswerken. Dit kan grote gevolgen hebben voor de afgrensbaarheid van werken en het privéleven en op de tijd die wordt besteed aan werken. Tabel 5 laat zien dat het telewerken in Europa van 2000 op 2005 is gestegen, en dat de werkenden in Nederland dit naar verhouding vaker doen. In Nederland doet recentelijk, in de periode 20072009 , ongeveer 11-13\% van de werknemers aan telewerken, zie tabel 6 .

Ten slotte de werk-thuisbalans. De Europese cijfers over 2000-2005 in tabel 5 geven aan dat de werk-thuisbalans in Nederland iets gunstiger is dan in Europa gemiddeld. ${ }^{4}$ Dat zal mede met onze deeltijdcultuur te maken hebben.

Minder uren of in deeltijd werken helpt bij het herstellen van de druk van het werk en bij het voorkomen van werk-thuis- of thuis-werkinterferentie. Het zou echter heel goed kunnen betekenen dat in de tijd dat er wordt gewerkt ook zeer intensief wordt gewerkt en dat de werkdruk in werktijd dus zeer hoog is.

Meer deeltijdflexibiliteit in het werk, onder andere als gevolg van telewerken, zou in Nederland verantwoordelijk kunnen zijn voor de afvlakking van de ervaren werkdruk, maar mogelijk ook voor de toename in overwerk gedurende het laatste decennium. Mogelijk is het jaar 2009 het jaar waarin de effecten van de recente crisis ten volle tot uiting komen. Of dat waar is, is op dit moment echter nog niet vast te stellen.

Voor de recente periode 2005-2009 lijkt er sprake van een lichte trend waarbij de negatieve invloed van het werk op de thuissituatie iets is afgenomen, zowel bij mannen als bij vrouwen (tabel 6 , onderaan). Wel zegt nog altijd ongeveer $50 \%$ van de werknemers dat het werk negatief van invloed is op familie- of gezinsactiviteiten.

Een negatieve invloed van de thuissituatie op het werk komt veel minder vaak voor. Het feit dat mannen deze beide vormen van disbalans iets sterker ervaren dan vrouwen, komt wellicht doordat zij ook meer uren werken, zowel volgens contract als ook door meer uren structureel overwerken.

\section{Conclusies en discussie}

In de inleiding is aangegeven dat tegen de achtergrond van globalisering, een verschuiving van werkgelegenheid naar de dienstensector en technologische vernieuwingen, een aantal veranderingen in de kwaliteit van de arbeid mag worden verwacht. Een deel van deze verwachtingen wordt empirisch bevestigd door de Nederlandse en Europese trends, maar andere niet. Zo is er in Nederland niet langer sprake van een sterke intensivering van werk. Aan het einde van de twintigste eeuw zagen we na een aanvankelijk gestage toename van het werktempo, de tijdsdruk en taakeisen een afvlakking optreden, die zich voortzette tot in deze eeuw.

De verwachte intensivering van werk is dus wel duidelijk zichtbaar in de cijfers die zijn gepresenteerd voor Europa als geheel. Het is niet geheel duidelijk waarom Nederland zich op dit punt zo onderscheidt van Europa. Er lijkt in Nederland sprake van een 'plafond-effect': in andere landen loopt men de Nederlandse werknemer voorbij waar 
het gaat om werkintensivering. Voortbordurend op het onderzoek van Gallie (2005), waarin een link wordt gelegd tussen het vele deeltijdwerk en de dalende of stabiliserende werkdruk in Nederland, is de lichte teruggang in het gerapporteerde aantal uren overwerk, van gemiddeld zeven naar zes uur per week in de periode 2005-2009, mogelijk een additionele verklaring voor de stabilisering van de door werkend Nederland ervaren tijdsdruk. Maume en Purcell (2007) geven ook aan dat in de VS de toegenomen ervaren intensivering voor driekwart wordt verklaard door de economische ontwikkelingen, maar dat de complexiteit van het werk, alsook het aantal uur voorspellend is. In Nederland is niet alleen het gemiddelde aantal uren werk maar ook de complexiteit van het werk ook wat afgenomen. Dit zou in lijn zijn met de gevonden afvlakking en zelfs lichte afname van de ervaren werkdruk.

Over de ontwikkelingen in de regelmogelijkheden of autonomie parallel aan de ontwikkeling in werkdruk weten we veel minder, omdat deze aanvankelijk niet of nauwelijks door het CBS werd gemeten. Het zelf beslissen over hoe het werk uit te voeren, liet vanaf 1994, toen het voor het eerst met één vraag werd gemeten, tot 2002 echter wel een gestage stijging zien (Houtman et al., 2004). Het nationale en internationale onderzoek laat echter een tegenstrijdig beeld zien. Nederlands onderzoek toont een min of meer continue stijging van autonomie sinds midden jaren negentig. Onderzoek naar de Deense situatie laat een zelfde beeld zien tot 2000 (Burr et al., 2003). Maar Pejtersen en Kristensen (2009) rapporteren voor de Deense situatie - met een wat andere survey over de periode 1997-2005 een daling van de autonomie. De in dit artikel gepresenteerde internationale cijfers laten voor Nederland een lichte daling in de autonomie zien in de periode 1995-2005 (tabel 1). Vooralsnog gaan we ervan uit dat de betrouwbaarheid waarmee de Nederlandse nationale NEA-gegevens aspecten van werk zoals autonomie worden gemeten, betrouwbaarder zijn dan die met de EWCS worden vastgesteld, omdat de nationale steekproeven consequent veel grotere en representatieve steekproeven betroffen. Een bijkomend probleem met de nationale verzameling van gegevens is wel dat autonomie in het werk nog niet erg lang door het CBS werd gemeten, en er in de periode van 2003 tot 2007 sprake was van trendbreuken. De NEA-trend sinds 2007 - die licht stijgend is - is echter uitermate betrouwbaar. In het kader van de duiding van verschillen in autonomie en andere aspecten van werk tussen Nederlandse en Europese gegevens, zal de 2010 meting van de European Working Conditions Survey (EWCS) hopelijk meer licht werpen.

Daarnaast is er een duidelijke trend in Nederland en Europa zichtbaar, die duidt op een afname van het monotone werk en toename van het 'leren van nieuwe dingen' (tabel 1). Ook hier zijn de ontwikkelingen onder de Nederlandse werknemers veel gunstiger dan die in Europa als geheel. Verondersteld wordt dat het hebben van gevarieerd werk en werk waarin je nieuwe dingen leert gunstige voorwaarden biedt voor het duurzaam inzetbaar blijven van werknemers, iets dat momenteel als heel belangrijk voor de toekomstige arbeidsmarkt wordt gezien. De Nederlandse gegevens suggereren echter wel dat de recente recessie een einde maakt, mogelijk tijdelijk, aan deze gunstige ontwikkeling. De waargenomen afname is echter alleen zichtbaar in 2009, maar betreft wel diverse indicatoren van leer- en ontplooiingsmogelijkheden, alsook het aanbod van cursussen door werkgevers (Koppes et al., 2010).

Door de toename van de dienstensector komen meer werknemers in het kader van hun werk in contact met klanten, patiënten, leerlingen of passagiers. In Nederland is echter geen toename te zien in het percentage werknemers dat melding maakt van 
agressie en geweld in het werk. Kennelijk is de link tussen de groei van de dienstensector en agressierisico's minder sterk, of wordt deze beïnvloed door andere factoren. Wanneer agressie en geweld binnen de sectoren waar veel contact is met 'derden' worden geanalyseerd, zoals de gezondheidszorg, het openbaar bestuur of de horeca, dan is hier ook geen stijging waarneembaar van het percentage werknemers dat lichamelijk geweld rapporteert. Wel valt te zien dat het lichamelijk geweld in deze sectoren relatief hoog is. Zo zegt een vijfde van de werknemers in de zorg het afgelopen jaar dat ze met fysiek geweld te maken hebben gehad, terwijl dat in de industrie slechts door één op de honderd werknemers wordt gemeld (Koppes et al., 2010).

Het 'nieuwe werken' met computers lijkt in Nederland een enorme vlucht te nemen. We staan Europees aan de top als het gaat om het gebruik van de computer en het telewerken. Beide indicatoren laten een gestage toename zien. Het werken met de computer blijkt bovendien samen te hangen met een gunstige kwaliteit van de arbeid, zoals gevarieerd werk, leer- en ontplooiingsmogelijkheden, complex werk, met veel werkdruk maar ook met veel autonomie, alsook met minder lichamelijke en omgevingsrisico's (Klein Hesselink et al., 2009). Hierbij dient opgemerkt te worden dat die samenhang ook te maken zou kunnen hebben met de aard van het werk dat voor computerisering in aanmerking komt. Dat is vaak hooggeschoolde mentale arbeid en niet zozeer zware fysieke arbeid. Een nadere toegespitste analyse lijkt hier zinvol.

De keerzijde van de trend in computergebruik is wel dat de Nederlandse werknemers langer achter de computer zitten: het percentage werknemers dat langer dan zes uur per dag achter het beeldscherm zit neemt toe. Aangetoond is dat zes uur of meer achter de computer zit een verhoogd risico heeft op klachten van het bewegingsapparaat. Onder vrouwen ligt deze grens al bij vier uur per dag (Blatter et al., 2000).

Niet onvermeld mag blijven dat in de cijfers de recessie een duidelijke rol speelt. Zo is er in Nederland in de recente jaren 2007-2009 een duidelijke stijging waarneembaar in de baanonzekerheid.

In het begin van dit artikel hebben we opgemerkt dat Nederland feminiseert en vergrijst, diverser en hoger opgeleid wordt. We kunnen niet op al deze invalshoeken in gaan. Wel valt op te merken dat bij enkele relevante werkkenmerken er sprake was van opvallende sekseverschillen in arbeidsomstandigheden. Die zijn met name te vinden op het punt van agressie en geweld op het werk en bij de lichamelijke en omgevingsbelasting op het werk. Maar in nagenoeg geen van deze gevallen betrof dit een sekseverschil in de richting van de trends op zich. Alleen waar het gaat om het doen van gevaarlijke werk is bij vrouwen sprake van een stijging en bij mannen niet. Vooralsnog is het onduidelijk of dit trendverschil te verklaren is door het feit dat mannen en vrouwen verschillend werk doen, en de werkgelegenheid in sectoren waar vrouwen werken én gevaarlijk werk doen, ook daadwerkelijk toegenomen is. Mannen en vrouwen doen deels verschillend werk, en dit verklaart vaak het verschil in arbeidsrisico's. Daarnaast hebben vrouwen, vaker dan mannen, een taak in het huishouden en het gezin waardoor ze bewust kiezen voor een minder omvangrijke en soms ook minder invloedrijke, maar dan ook minder belastende baan. Uit de hierboven beschreven trend blijkt echter niet dat werkende vrouwen in toenemende mate een risicogroep zijn.

Ten slotte nog even ingezoomd op Nederland binnen Europa. In een vergelijking van de werkbelasting van werkenden in Nederland en Europa, blijkt dat de lichamelijke 
belasting toch als significant minder hoog wordt beoordeeld door de werkenden in Nederland (zie figuur 3). Nederland springt er tevens gunstig uit ten aanzien van regelmogelijkheden, ontplooiingsmogelijkheden en sociale steun op het werk. Het werken in Nederland lijkt dus minder belastend dan dat gemiddeld in Europa het geval is, met uitzondering van lichamelijk geweld, dat in Nederland wel een probleem is.

Figuur 3 De arbeidsomstandigheden van werkenden in Nederland vergeleken met die in Europa anno 2005

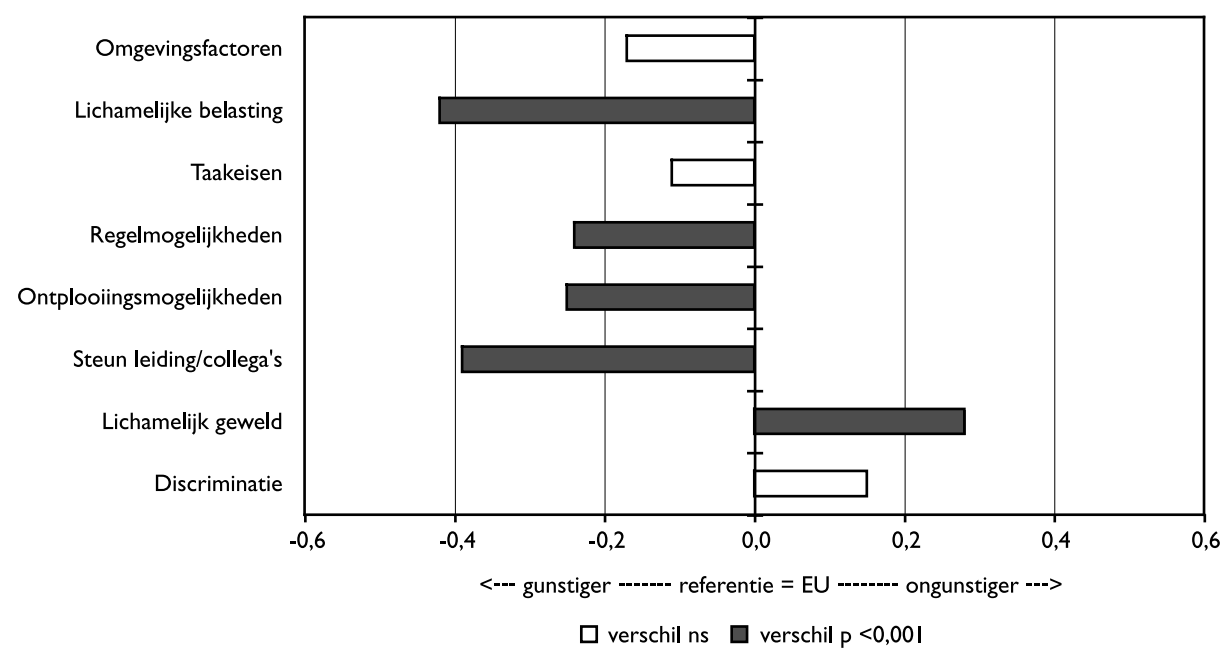

Bron: EWCS 2005 ( $n$ NL = I00I; $n$ EU-27 = 25.6I3; EU-27 = middenlijn)

Wat betreft de daling van het lichamelijk zwaar werk zij verwezen naar Johnson (2004) die ook in de Verenigde Staten een dergelijke afname waarneemt, maar tegelijkertijd opmerkt dat de lichamelijke belasting in de zware beroepen niet afneemt. Dit zou betekenen dat er specifieke risicogroepen zijn die niet of minder makkelijk langer doorwerken. Men kan hierbij denken aan de laagopgeleiden (Johnson, 2004). In het algemeen kunnen de hier gepresenteerde plus- en minpunten in de kwaliteit van de arbeid in Nederland van belang zijn voor de discussie over de arbeidsparticipatie en het langer doorwerken.

Op een beperkt aantal punten kan geconcludeerd worden dat arbeidsomstandigheden in Nederland zich ongunstig ontwikkelen. Met name is aandacht nodig voor het toenemend percentage werknemers dat meer dan zes uur per dag (voor werk) aan de computer zit en het relatief hoge percentage werkenden dat wordt geconfronteerd met uitingen van agressie en geweld in specifieke sectoren. Echter, vanuit een Europees perspectief gekeken naar de ontwikkeling van diverse indicatoren van de kwaliteit van de arbeid, steken werkenden in Nederland systematisch gunstig af. Nog in 2010 komen de nieuwe gegevens van de EWCS 2010 beschikbaar, waardoor nadrukkelijker kan worden bekeken of Nederland in de context van het Europa van nu zijn gunstige arbo-profiel overeind houdt. 


\section{Noten}

1 Het LSO (LeefSituatie Onderzoek) is van 1977 tot en met 1991 iedere drie jaar uitgevoerd. In 1991 werd dit onderzoek jaarlijks en werd het 'Doorlopend Leefsituatie Onderzoek (DLO) genoemd. In 1997 werd de opzet van het DLO gewijzigd en was er niet meer sprake van een eenmalige meting per jaar maar van een doorlopende selectie en bevraging van respondenten: de POLS (Permanent Onderzoek LeefSituatie). Het LSO, DLO en POLS zijn representatieve steekproeven ( $n=3.000-6.000)$ van de Nederlandse beroepsbevolking (www.cbs.nl).

2 De voorlopige analyses van de vijfde EWCS in 2010 duiden op hoofdlijnen op een stabilisatie ten opzichte van 2005.

3 Tot de EU-15 behoren België, Denemarken, Duitsland, Griekenland, Italië, Spanje, Frankrijk, Ierland, Luxemburg, Nederland, Portugal, Verenigd Koninkrijk, Finland (vanaf 1995), Zweden (vanaf 1995), Oostenrijk (vanaf 1995).

4 Hier moet worden bedacht dat in dit Europese bestand ook zelfstandigen vertegenwoordigd zijn.

\section{Literatuur}

Bakhuys Roozeboom, M., Gouw, P., Hooftman, W., Houtman, I. \& Klein Hesselink, J. (2008). Arbobalans 2007/2008. Hoofddorp: TNO Kwaliteit van Leven/Arbeid.

Bijl, R. Boelhouwer, J., Pommer, E., Schyns, P. (2009). De sociale staat van Nederland 2009. Den Haag: Sociaal en Cultureel Planbureau.

Blatter, B.M., Bongers, P.M., Kraan, K.O. \& Dhondt, S. (2000). RSI klachten in de werkenden populatie: de mate van voorkomen en de relatie met beeldschermwerk, muisgebruik en andere ICTgerelateerde factoren. Hoofddorp: TNO Kwaliteit van Leven.

Bongers, P.M., Kremer, A.M. \& Laak, J. ter (2002). Are psychosocial factors, risk factors for symptoms and signs of the shoulder, elbow, or hand/wrist? A review of the epidemiological literature. American Journal of Industrial Medicine, 41, 315-342.

Burr, H., Bjorner, J.B., Kristensen, T.S., Tüchsen, F., Bach, E. (2003). Trends in the Danish work environment in 1990-2000 and their associations with labor-force changes. Scandinavian Journal of Work, Environment \& Health, 29, 270-279.

Cuyper, N. De, Jong, J. De, Witte, H. De, Isaksson, K., Rigotti, T. \& Schalk, R. (2008). Literature review of theory and research on the psychological impact of temporary employment: Towards a conceptual model. International Journal of Management Reviews, 10, 25-51.

European Agency for Safety and Health at Work (EU-OSHA) (2007). Expert forecast on emerging psychosocial risks related to occupational safety and health. Luxembourg: Office for Official Publications of the European Communities.

Flanagan, R.J. (2006). Globalization and labor conditions. New York: Oxford University Press.

Gallie, D. (2005). Work Pressure in Europe 1996-2001: Trends and Determinants. British Journal of Industrial Relations, 43, 351-375.

Häusser, J.A. Mojzisch, A., Niesel, M. \& Schulz-Hardt, S. (2010). Ten years on: A review of recent research on the job-demand-control (-support) model and psychological well-being. Work \& Stress, 24, 1-35.

Houtman, I., Douwes, M., Jong, T. de, Meeuwsen, J.-M., Jongen, M., et al. (2008). New Forms of Physical and Psychosocial Risks at Work. Luxemburg: European Parliament (IP/A/EMPL/ FWC/2006-205/C1-SC1).

Houtman, I.L.D., Smulders, P.G.W. \& Klein Hesselink, D.J. (2004). Trends in arbeid 2004. Hoofddorp: TNO Arbeid.

Johnson, R.W. (2004). Trends in job demands among older workers 1992-2002. Monthly Labor Review, 127, 48-56.

Karasek, R. \& Theorell, T. (1990). Healthy Work. London: Basic Books.

Kawachi, I. (2008). Globalization and workers'health. Industrial Health, 46, 421-423.

Kivimäki, M., Virtanen, M., Elovainio, M., Kouvonen, A., Väänänen, A. \& Vahtera J. (2006). Work stress in the aetiology of coronary heart disease - a meta-analysis. Scandinavian Journal of Work and Environmental Health, 32, 431-442.

Klein Hesselink, J., Houtman, I., Hooftman, W. \& Bakhuys Roozeboom, M. (2009). Arbobalans 2009. Hoofddorp: TNO. 
Koppes, L., Vroome, E. de, Mol, M., Janssen, B., Bossche, S. van den (2010). Nationale Enquête Arbeidsomstandigheden 2009. Hoofddorp: TNO.

Maume, D.J. \& Purcell, D.A. (2007). The 'over-paced' American: recent trends in the intensification of work. Research in the Sociology of Work, 17, 251-283.

Pejtersen, J.H. \& Kristensen, T.S. (2009). The development of the psychosocial work environment in Denmark from 1997 to 2005. Scandinavian Journal of Work \& Environmental Health, 35, 284-293.

Peña-Casas, R. \& Pochet, P. (2009). Convergence and divergence of working conditions in Europe: 1990-2005. Luxembourg: European Foundation for the Improvement of Living and Working Conditions

Sanders, J., Lautenbach, H., Smulders, P. \& Dirven, H.J. (2010). Alle hens aan dek; niet-werkenden in beeld gebracht. Hoofddorp: TNO Kwaliteit van Leven.

Smulders, P.G.W. (2008). Balans van twee decennia kwaliteit van de arbeid. In S. Dhondt \& F. Vaas (Red.), Waardevol werk (pp. 87-99). Den Haag: Lemma

Smulders, P. \& Goudswaard, A. (2010). Werk en arbeidsvoorwaarden van flexwerkers. EconomischStatistische Berichten, 95, 618-620.

Stansfeld, S. \& Candy, B. (2006). Psychosocial work environment and mental health - a metaanalytic review. Scandinavian Journal of Work Environment and Health, 3, 443-462.

Ybema, J.-F., Geuskens, G. \& Oude Hengel, K. (2009). Oudere werknemers en langer doorwerken. Hoofddorp: TNO Kwaliteit van Leven/Arbeid. 